This item was submitted to Loughborough's Research Repository by the author.

Items in Figshare are protected by copyright, with all rights reserved, unless otherwise indicated.

\title{
The continuity of underperforming ICT projects in the public sector
}

\section{PLEASE CITE THE PUBLISHED VERSION}

http://dx.doi.org/10.1016/j.im.2014.06.002

\section{PUBLISHER}

(c) Elsevier

\section{VERSION}

AM (Accepted Manuscript)

\section{PUBLISHER STATEMENT}

This work is made available according to the conditions of the Creative Commons Attribution-NonCommercialNoDerivatives 4.0 International (CC BY-NC-ND 4.0) licence. Full details of this licence are available at: https://creativecommons.org/licenses/by-nc-nd/4.0/

\section{LICENCE}

CC BY-NC-ND 4.0

\section{REPOSITORY RECORD}

Sandeep, M.S., and M.N. Ravishankar. 2019. "The Continuity of Underperforming ICT Projects in the Public Sector”. figshare. https://hdl.handle.net/2134/17100. 


\title{
The continuity of underperforming ICT projects in the public sector
}

\begin{abstract}
There is a growing body of research on the successes and failures of information and communications technology (ICT) projects in the public sector. However, this literature has rarely addressed the question: why do some projects persist and continue despite functioning poorly in several areas. In this paper, we suggest that the notions of institutional logics and status differences provide useful insights into the structure and trajectory of such a continuity. We build our arguments through an in-depth qualitative case study of a public information and communications technology (PICT) project in India. From our findings, we develop a process model of PICT project continuity. We explain how bureaucratic posturing - a manifestation of bureaucratic logic - when employed as a tactic by high status groups, lead to poor performance on several fronts. The paper elaborates on two levels of continuity: policylevel continuity, which in our case was enabled by the logics of decentralization and technocracy, and operational-level continuity, which was achieved when groups with contrasting status-related motivations supported the project.
\end{abstract}

Keywords: PICT project continuity, Public sector, Institutional logics, Status differences, India, Case study 


\section{Introduction}

Within public-sector settings information and communications technology (ICT) is now viewed as a catalyst of growth and transformation [49, 50]. Governments are increasingly initiating innovative projects by leveraging the power of ICT [see 28, 34]. It is widely acknowledged that diffusion of such public information and communications technology (PICT) ${ }^{1}$ projects is a key driver for inclusive development and better governance [18, 33]. Unlike their private sector counterparts, which are almost always concerned only with business objectives, ICT deployments in the public sector aim to use technology extensively to also address issues of social inclusion, transparency, decentralized delivery of public services, public accountability and governance $[8,19,46]$. Increasingly, many PICT projects are also launched with the objective of cutting down costs in government departments [19]. While they share many characteristics with other public sector initiatives, PICT projects are distinctive in that their outcomes are intimately connected with the properties inscribed in ICT and with how human actors' attribute multiple meanings to, and socially shape, technology.

The actual impact of such ambitious PICT projects remains a point of much debate with some studies suggesting that $60-80 \%$ of them end in failure [see 19]. Especially in settings that are similar to this paper's empirical sections (i.e., emerging economy contexts) there is even more emphatic evidence that PICT projects don't do very well. Choudhuri [8] points out that despite receiving overwhelming support from stakeholders, PICT projects in a number of emerging economy sectors have struggled to meet their objectives. For instance, dubious outcomes in the case of health-sector PICT projects have been vividly demonstrated and discussed at length [see 30, 38, 39, 40]. A more recent example which underlines the question marks surrounding PICT projects is India's Unique Identification Project [see 15,

\footnotetext{
${ }^{1}$ The term 'PICT projects' refers to ICT projects where governmental agencies play a leading role.
} 
31]. This project seeks to associate every citizen with a unique identification number in order to help them gain better access to government programs and other essential services. However, since its initiation the project has become entangled in so many difficult political and ideological disputes that it appears to be a long way off from meeting any of its intended goals [see 31].

Although extant studies have documented many instances of PICT projects whose objectives were not met, there remains an important gap in the literature. Very few studies have examined how and why some PICT projects persist and continue when they are clearly underperforming in many areas. To better understand the processes underlying such a continuation of PICT projects, we draw on the notion of institutional continuity [25, 42]. Here, we apply the idea of continuity to the specific case of PICT projects and define PICT project continuity as the long-term persistence of underperforming PICT projects. Analyzing and explaining the influences on continuity can provide important insights into the forces that shape the trajectory of PICT projects. They also help develop a deeper understanding of PICT projects and may challenge the conventional wisdom that successful projects continue and poorly performing ones get terminated. From a practical perspective, an in-depth analysis of continuity can alert public policy designers to potential structural weaknesses underlying PICT projects.

While there is scarce research on the continuity of underperforming PICT projects, some studies, although not focusing on continuity per se, provide important clues about this phenomenon. These studies can be broadly categorized into two groups. The first group of studies seem to relate continuity of projects to the dominance of institutional norms and discourses. For instance, drawing on a study of an innovative PICT project in India, Ravishankar [34] suggests that certain cultural contexts might be normatively inclined to tolerate projects, even when the trajectories of such projects are ambiguous and their 
outcomes uncertain. In a similar vein, other empirical research has implicitly linked the sustainability of innovative PICT projects to institutional perceptions about distributive justice [see 30], accountability [see 43] and political expediency [see 6]. Broadly, this first group of studies indicate that the embedded norms, beliefs and perceptions in an institutional environment may have a significant bearing on PICT project continuity. In other words, they suggest that particular institutional logics [12, 27, 40, 45] could guide projects through difficult periods and weak outcomes. Hence our first research question in this paper is: How do institutional logics influence PICT project continuity?

A second group of studies point to the likely influence of vested interests on the continuity of projects. Keil [21] showed how competitive rivalries between groups and the desire to protect one's status can result in an escalation of commitment to a failing IT project. Similarly, Allen [1] points out that because of their interest in maintaining status-quo, actors tend to adopt a variety of tactics that render technology commitments 'irreversible'. In general, this group of studies suggest the continuity of projects may also be linked to differences in status and to focused human efforts to protect such extant hierarchical structures. Hence our second research question in this paper is: How do status differences influence PICT project continuity? In the following sections, we present a review of the literature on institutional logics and status differences and their possible relevance to PICT projects.

\section{Institutional Logics}

The notion of institutional logics is a key concept in institutional theory. Thornton and Ocasio [44, p.804] define institutional logics as "the socially constructed, historical pattern of material practices, assumptions, values, beliefs, and rules by which individuals produce and reproduce their material substance, organize time and space, and provide meaning to their 
social reality”. In simpler terms, institutional logics are socially shared cultural beliefs and assumptions that shape the cognitions and behaviours of actors [27, 12]. When different groups in a setting adhere to different logics, agreements are difficult to reach and consensus can be elusive [12, 16, 49]. Groups may collaborate, compete, or choose to remain divided depending on the underlying beliefs of their respective institutional logics. Indeed, in a given institutional environment multiple institutional logics can compete [27, 40, 49], resulting in one of three possible outcomes: (1) emergence of a single dominant logic [11], (2) coexistence of multiple logics in the absence of a single dominant logic [36] and (3) short-lived dominant logics marked by constant change [45].

In the specific case of PICT projects, research has shown how particular institutional logics may guide and influence implementation outcomes [9, 40, 49]. For example, in a study of a geographical information system (GIS) project in the Indian forestry sector, Walsham and Sahay [49] demonstrated how an embedded political logic guided most forest management decisions, while at the same time a contradictory scientific-modelling logic prescribed GIS-enabled ways of managing forests. Walsham and Sahay [49] argued persuasively that the conflicts created by the simultaneous presence of these two logics had a detrimental effect on the performance of the GIS project. Similarly, in an action research project featuring an IT-enabled health management information system (HMIS) in Tajikistan, Sahay et al. [40] showed how attempts to replace a historically powerful set of institutional logics can be a futile exercise in the absence of support from influential political actors. This inability to replace and transform deeply embedded logics can indeed lead to the failure of well-intentioned projects [see 6]. More recently, some research has highlighted the possibility that the application of specific institutional logics may contribute to the continued underperformance of a PICT project. For example, in an empirical study of the Bangalore One project, Ravishankar [34] notes that a logic of 'ambiguity tolerance' employed by the 
private partners facilitated the continuity of the project at crucial junctures. Although this study focuses more on the successes of the project and does not explicitly refer to the term 'logic', it is evident in the paper that the same logic of ambiguity tolerance was also responsible for many of the poor outcomes of the project. Overall, it seems that the notion of institutional logics has the potential to add a novel and useful dimension to explanations of continuity. Therefore, as noted earlier, in this paper we explore its influence on PICT project continuity in greater detail.

\section{Status differences}

Status is "an effective claim to social esteem in terms of positive or negative privileges” [51, p. 305]. As Chen et al. [7] observe, hierarchies and differences in status permeate social and organizational life. According to them, there are two possible routes to social status: (a) dominance-based and (b) prestige-based. Dominance-based status - and by implication status differences - are realized and maintained by the application of 'coercion and aggression' whereas prestige-based status differences are created through 'respect, admiration, and deference'. Among the two, the former route is often blamed for poor outcomes of public projects. In other words, dominance-based approaches to maintaining status differences may push PICT projects to the brink [see 38].

While some scholars have argued that status differences have historically played a positive role in helping individuals to make cognitive adjustments and to manage their sense of self-entitlements [10], others have shown how status differences negatively affect learning [5], hinder multiparty collaboration [26, 35] and weaken performance of work-groups [3]. Invariably, every social order is characterized by status hierarchies with some groups enjoying a super-ordinate status and others occupying a subordinate status [14, 41, 52]. Different characteristics or markers (such as age, gender, and professions) can signify high 
and low status groups in different cultures [see 4, 41]. For instance, the Indian caste system is an established social order which determines based on birth, whether one belongs to a higher caste or a lower caste. Here, caste can be viewed as an important characteristic or marker of status. Levina and Vaast [26] list four types of status characteristics, which may give rise to status differences: (1) economic capital (2) intellectual capital (3) social capital and (4) symbolic capital. Greater access to these capitals leads to a higher status and vice versa.

Kellogg [22] has argued that a high status group is threatened when a low status group starts competing for a set of resources hitherto reserved for the former. As a reaction to such 'status threats', the high status group may engage in a series of status quo maintaining actions. Kellogg [22] refers to individuals in such high status groups who strive to maintain status quo in the event of a threat as internal defenders of status. A corollary of these arguments about status is that low status groups may also fight hard to improve their own status. These dynamics of status differences and threats are strongly reflected in the empirical sections of this paper as well. Despite their likely relevance to the implementation and sustainability of projects, in the broader management literature there appears to be very little published research on PICT projects and status differences. One notable exception is Sahay et al.’s [38] action-research based study of a health PICT project in Andhra Pradesh, India. This study showed how the entire machinery of the state was galvanized to support the continuity of a politically 'high status' family health information monitoring system (FHMIS), and to sabotage a relatively 'low status', but effective, district health information system (DHIS). Similarly, research on continuity of ICT projects in the private sector point to ways in which the dynamics of status structures could be linked to the sustainability of projects. In a study of an expert IT system designed to help sales representatives, Keil [21] suggested that influential actors offer support and protection to failing projects because they help them in 'empire building' and equally, the termination of such projects could severely diminish their high 
status. These studies suggest that the notion of status differences can be a particularly useful analytical lens to apply to a study of PICT project continuity. They also raise the question of whether status differences could indeed remain unaltered forever [see 3, 41].

In summary, a review of the literature shows that governments are moving towards an era of high investments in ICT in order to improve governance processes and delivery of public services. There is scant research into PICT projects that continue despite underperforming in several areas. In this paper we address this gap by drawing on the notions of institutional logics and status differences as theoretical lenses. In the next sections, we present an in depth case study of an Indian PICT project and examine the simultaneous influence of institutional logics and status differences on continuity.

\section{Research Methods}

As noted above, we conducted an in-depth case study. Our approach to the case study was informed by the interpretivist philosophy, which emphasizes the social construction of reality and focuses on the inter-subjective realities of actors [see 24,48 ]. Our initial desk research gave us some pointers at a general level, about key issues that may emerge during the implementation of PICT projects. In the main, the literature suggested that the trajectory and continuity could be intimately connected with the embedded belief systems and the maintenance of status-related advantages for privileged groups. Thus, the notion of institutional logics and status differences served as broad sensitizing devices [47] for our study. In other words, while we expected them to provide some insights into PICT project continuity, we did not apriori hypothesize about the mechanisms and processes through which these sensitizing devices could influence project continuity.

\subsection{Research setting}


The PICT project refers to the implementation of a public ICT system in an Indian provincial state. We use the term 'state' in the rest of the paper to refer to this provincial state. Four major types of groups are involved in the PICT project. These groups are summarized in Figure 1 and Table 1 below. (1) GOV-S groups are state level departments and comprise elected representatives and bureaucrats. They are primarily involved in the implementation of a number of state programs in sectors such as rural development, public health, education and water supply. (2) GOV-L groups are the local level counterparts of the GOV-S groups. They are situated at the local level, i.e. at the district and sub-district levels (see Fig. 1 below). Structurally, they mirror their respective GOV-S departments. (3) The TRES-S group is the state level treasury unit. This group coordinates and manages the operations of the PICT project at the state level. (4) TRES-L groups are the treasury units at the local level. Each TRES-L group is attached to a unique GOV-L group, whose funds they co-ordinate and manage through the PICT project.

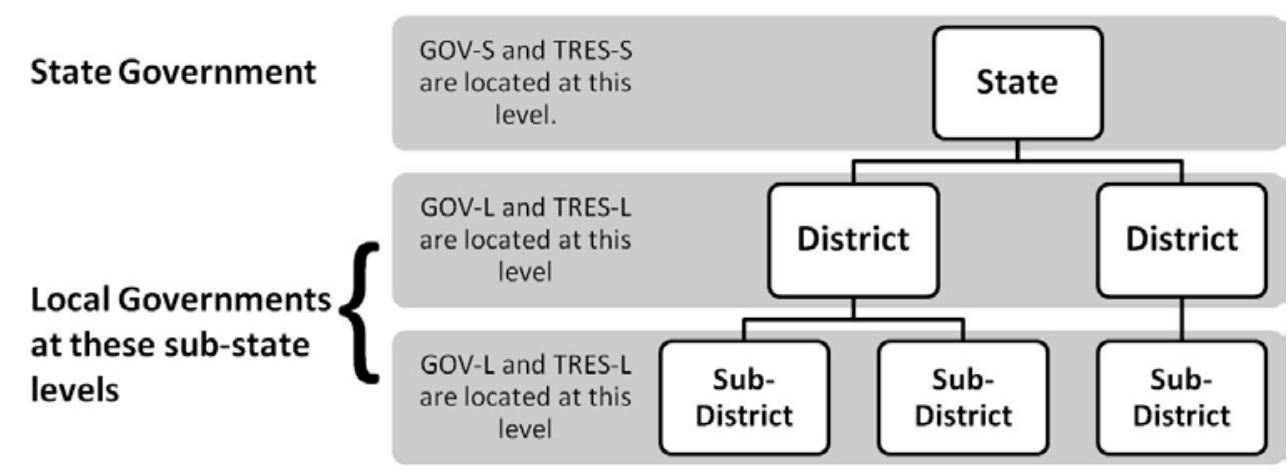

Figure 1. Administrative structure

At the start of the financial year, the finance department of the state sets the budget for the entire state. Accordingly, funds are released to different departments of the government. Through the PICT project the management of this process was transformed from a manual process to a supposedly more effective and transparent computerized system. The 
project aims to eliminate the systemic inefficiencies in the earlier manual system and ensure fairer allocation and equitable distribution of funds, in particular, to the historically disadvantaged GOV-L groups.

\begin{tabular}{|c|c|c|c|}
\hline Group & Members & Role & $\begin{array}{c}\text { Level of } \\
\text { operation }\end{array}$ \\
\hline GOV-S & $\begin{array}{c}\text { State-level } \\
\text { bureaucrats and } \\
\text { elected } \\
\text { representatives }\end{array}$ & $\begin{array}{c}\text { Policy making and } \\
\text { implementation }\end{array}$ & State level \\
\hline TRES-S & $\begin{array}{c}\text { State-level } \\
\text { bureaucrats }\end{array}$ & $\begin{array}{c}\text { Operational } \\
\text { management of the } \\
\text { PICT project }\end{array}$ & State level \\
\hline GOV-L & $\begin{array}{c}\text { Elected } \\
\text { representatives and } \\
\text { local government } \\
\text { bureaucrats }\end{array}$ & $\begin{array}{c}\text { Policy making and } \\
\text { implementation }\end{array}$ & Local level \\
\hline TRES-L & $\begin{array}{c}\text { Local-level } \\
\text { bureaucrats }\end{array}$ & $\begin{array}{c}\text { Operational } \\
\text { management of the } \\
\text { PICT project }\end{array}$ & Local level \\
\hline
\end{tabular}

Table 1. Description of groups

\subsection{Data collection}

Our research interest in the PICT project was triggered by the frequent mentions it received in the Indian popular press. Interestingly, most of the commentaries and reports over the years seemed to be bemoaning the inability of the project to live up to its promise. We were keen to find out why the project was not doing well and what forces kept it going, given the reported shortcomings. Access to the project was negotiated through a senior official of the state's finance department, who was an acquaintance of the first author. In return for access to the different groups involved in the PICT project, we were asked to provide a written report of our findings. This report, which we submitted soon after the data collection process, contained our qualitative assessment of the implementation of the PICT project. Broadly, this report outlined the findings presented in this paper, but was written less as an academic research paper and more as a list of recommendations for tackling the deeper 
problems facing the project. We collected four rounds of data during a nine-month period (see Table 2 below).

\begin{tabular}{|c|c|c|c|c|c|}
\hline Data Collection & GOV-S & $\begin{array}{c}\text { TRES- } \\
\text { S }\end{array}$ & GOV-L & TRES-L & $\begin{array}{c}\text { Number of } \\
\text { interviews }\end{array}$ \\
\hline $\begin{array}{c}\text { Round 1 } \\
\text { (August 2009) }\end{array}$ & - & - & 5 & 2 & 7 \\
\hline $\begin{array}{c}\text { Round 2 } \\
\text { (September 2009) }\end{array}$ & - & - & 3 & 2 & 5 \\
\hline $\begin{array}{c}\text { Round 3 } \\
\text { (November 2009) }\end{array}$ & $\mathbf{1 1}$ & $\mathbf{8}$ & $\mathbf{4}$ & $\mathbf{1}$ & $\mathbf{2 4}$ \\
\hline $\begin{array}{c}\text { Round 4 } \\
\text { (April 2010) }\end{array}$ & - & - & 3 & - & 3 \\
\hline
\end{tabular}

Table 2. Details of interviews

Our main source of empirical data was 39 semi-structured in-depth interviews with members of the four groups. Each interview lasted for about 45 minutes and was recorded and transcribed. Our informants included senior bureaucrats, elected representatives, middlelevel and junior-level clerks, treasury officers, case workers (low-ranking officials responsible for processing bills) and data-entry operators who operated the PICT system. Since all of them spoke to us on condition of anonymity, we have used fairly generic designations (e.g., GOV-L member) when quoting informants. We started a typical interview by asking broad questions about the informant's relationship with the state (or local) groups, and his experience as a user of the PICT system. As the interview progressed, we asked more detailed questions about what the PICT project meant to the local and state groups and how they benefitted (or not) from it. Informants spoke candidly and openly about their disagreements with other groups and about what they perceived as the 'root problems' and the 'major drawbacks' of the project. One possible reason for this frankness was that the interviewer (first author) was an Indian citizen and shared a similar socio-cultural background 
as the informants. Many informants went back in time and recalled their experiences during the initiation and development phases of the PICT project. They also elaborated on what they believed were the challenges in engaging with the state (or local) groups. In order to get a better sense of the objectives of the project and current 'official' thinking about its implementation, we reviewed secondary sources of data such as internal reports and minutes of meetings. We were conscious that official printed reports could paint an overly rosy picture of the project's trajectory. During the interviews, we tried our best to verify the claims made in official documents with a range of informants at different hierarchical levels.

\subsection{Data analysis}

A key theme, which permeated our data, concerned the relative status of the various groups. Through a detailed line-by-line analysis of our interview data and field notes, we arrived at four status markers which described the underpinnings of the status differentials between the groups. We were alerted and guided to the status markers by informants who described major discrepancies and asymmetries in the allocation of resources. The status markers we identified were: access to funds, access to infrastructure, access to skilled human resources, and ICT-readiness. Subsequently, we categorised groups as high status and low status based on where they stood in terms of the status markers. At this stage, we again conducted a detailed analysis of our field notes and developed three interpretive concepts, which seemed to accurately represent the overarching belief systems prevalent in the institutional environment: bureaucratic, decentralization, and technocratic. These belief systems aligned closely with the theoretical notion of institutional logics and were either well-aligned with the objectives of the PICT project or went against its aspirations. We accordingly coded them as complementary logic and competing logic respectively. 
Using this analysis we inductively built a tentative model to explain the influence of multiple institutional logics and status differences on the continuity of the project. We revisited the summaries and key quotes, and travelled back and forth iteratively from the data to the broader literature on PICT projects to look for possible alternative and additional explanations for continuity. During this phase of analysis, we found evidence of an additional influence on continuity. This concerned the agentic work of the low status groups, which also helped us better understand the nature of ground-level support available to the project. We incorporated this influence on continuity into the revised model. Through this process we augmented and strengthened our emerging model, until we reached a point where no further modifications seemed valuable. We thus developed our refined model and also ensured that a reasonable level of theory-data-model alignment was reached [see 32].

\section{Case Description}

The PICT project has been hailed as a precedent setter - at the time of its introduction there were no other similar deployments in India. The project began operations in 2003 and was extended to the state's local governments (the GOV-L groups) in 2007 with a view to providing these local bodies easy and transparent access to their allocated funds. Prior to the introduction of this project, the state's financial system faced a number of problems. For instance, the processing of bills, which were due for payment, was done manually. This led to many delays in updating budgets and issuing payments. GOV-L groups, which were scattered throughout the state, suffered the most as their requests for release of funds would get mired in this time-consuming process. In many cases, they would find that the money allocated to them had already been spent by another (usually their GOV-S counterpart) group. Indeed, it seemed the process of allocation of funds was severely skewed. Funds were mostly allocated on a first come first served basis leading to what can be termed as 'elite capture', i.e. 
influential GOV-S groups often over-withdrew funds. There was no system of audit trails to keep a tab on such practices. There were numerous reports of funds allocated for public service programs at local levels being diverted to other unrelated expenditure. The PICT project intended to use ICT extensively to tackle such inefficiencies.

\subsection{An overview of the PICT network topology and the process flow}

The PICT project operates in a distributed client-server model. Fig. 2 below depicts the overall network architecture of the PICT system. The main server and the satellite responsible for running the PICT system are located at the state level and are managed by the TRES-S group. These are connected to a number of client locations at the state and sub-state levels through a wide area network (WAN).

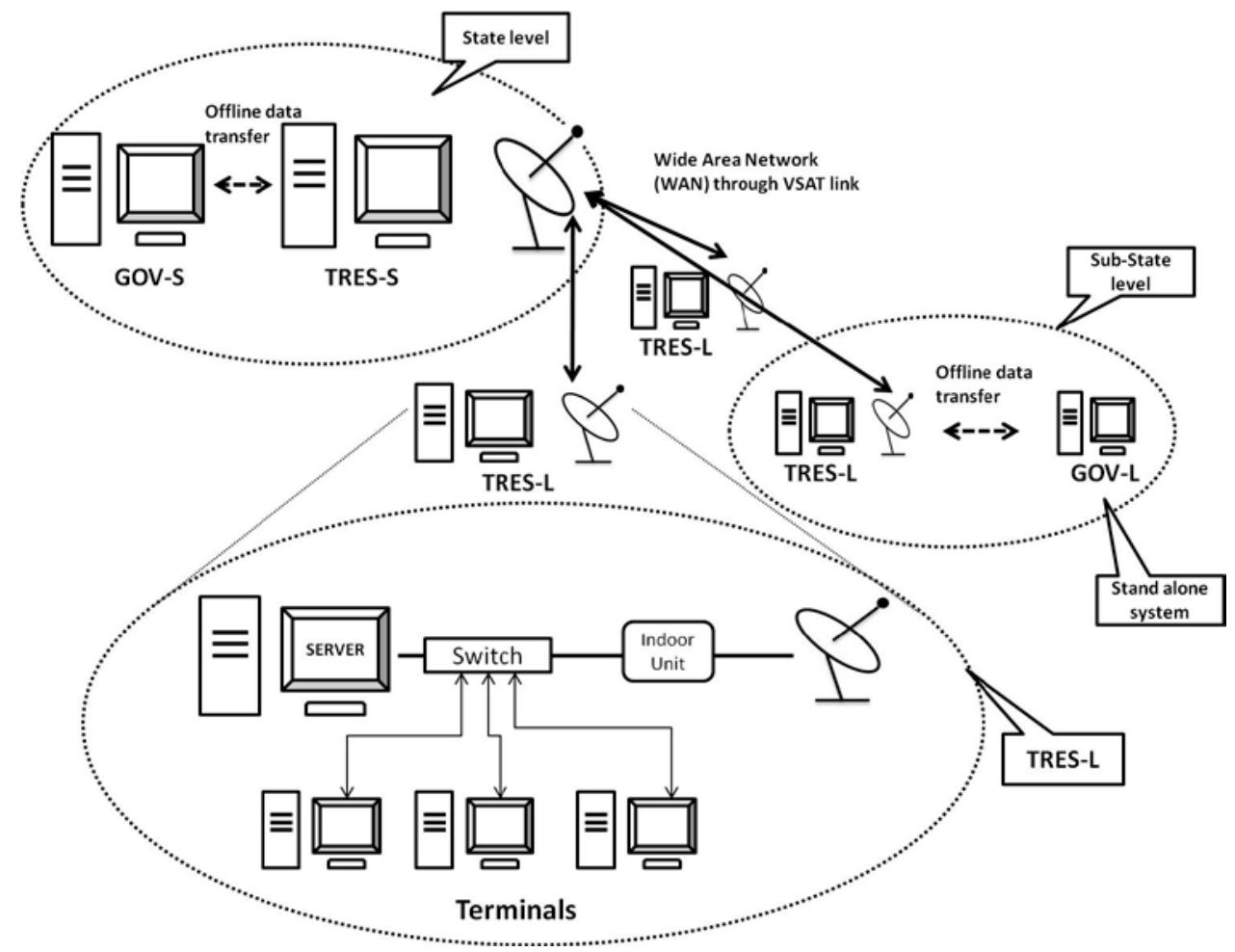

Figure 2. The PICT network topology

A typical process flow of a PICT project transaction is depicted in Fig. 3 below. When TRES-S is notified of the release of funds from the state's finance department, this information is updated on the central server of the PICT system. On receipt of the 
government order GOV-L groups across the state apply for the release of funds through the local TRES-L groups. The respective TRES-L group validates these applications with the central server located at TRES-S. Upon successful validation the funds are released to the GOV-L groups.

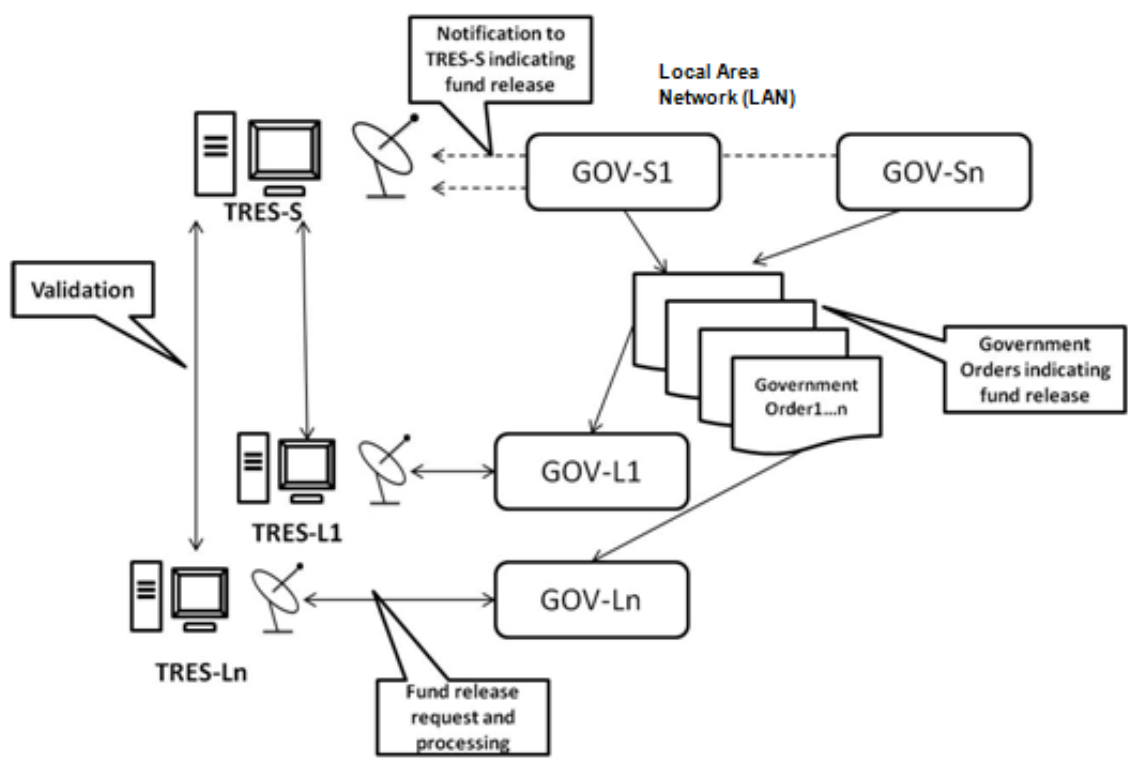

Figure 3. Overview of a typical process flow in the PICT project

\section{Findings}

As noted above, the PICT project is just over a decade-old. It aims to improve transparency and equity, remove asymmetries in allocation of funds, devolve greater power and control to local groups and provide local groups with real-time access to their funds. Although it intended to bring numerous benefits, in reality, the project has performed poorly in several areas. In particular, it has failed to provide GOV-L groups the opportunity to access funds in a timely and useful manner. The project's intention to devolve control to local groups has also remained largely unfulfilled. In this section, we explain the project's unfulfilled promises and the reasons for its continuity through an elaboration of the a) prevailing institutional logics and b) significant differences in status between the state and local groups. 


\subsection{Institutional logics and the PICT project}

In its implementation the PICT project was largely governed by the broader cultural norms and discourses operating in the institutional environment. There was a clear preference for strict top-down rules, tight central control of projects and imposition of bureaucratic procedures on local governments. In other words, a highly bureaucratic logic that believed in the virtues of central management of projects through formal rules and excessive procedures was applied to the PICT project. While they paid lip-service to the PICT project's objective of helping local governments, in practice the state groups used bureaucratic posturing and usurped most of the funds allocated to their department, rather than sharing it with their local group counterparts, as the project intended. Thus, the system of fund allocation continued to be skewed. As a GOV-S member put it:

Local governments are a nuisance. No work gets done. There is corruption and no accountability. The quality of development is also poor. They are inefficient and incompetent. It is better when we are handling everything.

Furthermore, although GOV-L groups were key stakeholders in the project, they were not given real time, online access to their fund status via the PICT system. While the project required the state groups to invest funds and connect (via networked computers) GOV-L offices to the PICT network, they refused to do so. Also, by introducing many 'GOV-S and TRES-S approval required' clauses into the system, the state groups made the process of obtaining access to funds a time-consuming manual process for GOV-L. This often led to confusion and delays and affected planning at the local group level. In short, the use of a bureaucratic logic manifested via heavy bureaucratic posturing ensured that control remained with the state groups. 
Although the bureaucratic logic frustrated their desire to have a bigger say in the implementation of the project, there were other institutional discourses that were clearly more favourable to the local groups. In particular, there was now a systemic belief in the values of decentralized forms of governance and administration. This focus on decentralization as a reasonable and legitimate way of administering public governance was provided constitutional impetus with the passing of a 'decentralization act' in 1992, which made it mandatory for state governments to create and nurture local governments. Thus, the institutional environment within which the development of the PICT system took place was also guided by a marked emphasis on decentralization. We may describe this as the decentralization logic. The local groups were strong adherents of the decentralization logic. As a GOV-L member argued:

We know the local realities; we know what is best for us. Why can't the state government give us what is rightfully ours?

Local groups pointed out that their 'perceived' needs were too often envisioned by state bureaucrats, who they felt had an inadequate understanding of local needs. Seen against this backdrop, the idea of devolution of power via the PICT project was very appealing. Local groups were committed to supporting this project, whose espoused objectives promised decentralization. Despite the continued problems created by the bureaucratic logic, they welcomed the project as an emancipatory tool of the future. In general, they viewed the project as an important manifestation of the state government's responsibility to bring the decentralization act into practice and to provide them with the resources necessary to function as effective local governments. This logic of decentralization also generated support for the PICT project in the local environment, even though in its current form the project did not live 
up to its promise. Despite complaints about how the project gave them very little control, the local groups felt that its noble aims also gave them hope for the future:

They say we will control things in the future. We feel that in the future the PICT project will certainly help us speed up our own work and give us more control over our funds. (GOV-L member).

The third overarching institutional logic that shaped and drove projects in this setting can be termed as the technocratic logic. Computerization of public services in India began in the mid-1990s. Since then there has been a growing sense of faith within the public sphere in the value and power of ICT tools. However, this technocratic logic is often taken to extremes wherein the implementation of an ICT project is seen as an end in itself, rather than as a means of delivering better governance. Thus, the technocratic logic was characterized by an unshakeable belief in the virtues of ICT. As a member of TRES-S noted:

The system is perfect, it is there, and tomorrow if someone asks me to change something I can't do anything about it. The system will do its job; it does not fail.

Some of the adjectives used by the GOV-S and TRES-S members to describe the PICT system were: “unfailing”, “strong” and "perfect”. Over a period, the PICT system had become a highly esteemed black box, not to be opened ever. The system was also imputed the characteristics of a faithful, trustworthy worker who never fails.

Clearly, multiple logics co-existed in the institutional environment. However, as explained above, not all logics were well-aligned with the aspirations of the PICT project. The bureaucratic logic, in particular, was locked in a tense and contested relationship with the aims of the project. The PICT project aimed to devolve power to local groups. But the beliefs of the bureaucratic logic openly contradicted this objective. Put differently, the tight central 
control and concentration of power prescribed by the bureaucratic logic went against the very spirit of what the PICT project was aiming to achieve. We may thus term the bureaucratic logic as a competing logic. The technocratic logic, by definition, favoured and showed faith in ICT projects. The PICT project was one such project, which had an explicitly stated commitment to the extensive use of ICT to remove the distortions of the manual system. Therefore, the technocratic logic completely supported the PICT project. In view of its support to the project, we may consider the technocratic logic as a complementary logic. Similarly, given its support for devolution of power to local governments, the decentralization logic was very well aligned with the aims of the PICT project. In this sense, we may view the decentralization logic too as a complementary logic. This categorization of the three logics is summarized in Table 3 below.

\begin{tabular}{|c|c|c|l|}
\hline $\begin{array}{c}\text { Institutional } \\
\text { logic }\end{array}$ & $\begin{array}{c}\text { Institutional } \\
\text { logic type }\end{array}$ & $\begin{array}{c}\text { Strong } \\
\text { adherents }\end{array}$ & \multicolumn{1}{|c|}{ Characterised by } \\
\hline Bureaucratic & Competing & $\begin{array}{c}\text { State } \\
\text { groups }\end{array}$ & $\begin{array}{l}\text { Top-down approach to planning } \\
\text { and decision making. Strong belief } \\
\text { in exercising centralized } \\
\text { bureaucratic control over local } \\
\text { governments. }\end{array}$ \\
\hline Technocratic & Complementary & $\begin{array}{c}\text { Both state } \\
\text { and local } \\
\text { groups }\end{array}$ & $\begin{array}{l}\text { Faith in the infallibility of } \\
\text { technology. Technology is seen as } \\
\text { an enabler and a key tool for } \\
\text { overcoming problems. }\end{array}$ \\
\hline Decentralization & Complementary & $\begin{array}{c}\text { Both state } \\
\text { and local } \\
\text { groups }\end{array}$ & $\begin{array}{l}\text { Belief in transferring power and } \\
\text { control to local governments; } \\
\text { emphasis on participatory planning } \\
\text { and decentralized decision making. }\end{array}$ \\
\hline
\end{tabular}

Table 3. Institutional logics: competing and complementary 


\subsection{Status differences and the PICT project}

While institutional logics are one way of accounting for how the project has unfolded, the overarching status differences between the groups also help explain why the promised benefits to the local groups have not materialized. The state groups clearly enjoyed a much higher status than the local groups. As with many typical centre-local relationships, the status differentials were most vividly demonstrated in the preferential allocation of key resources to the former, which has continued even though the PICT project intends otherwise (see Table 4 below for a summary).

\begin{tabular}{|c|c|c|c|c|}
\hline $\begin{array}{c}\text { Markers of } \\
\text { Status } \\
\text { Differences }\end{array}$ & GOV-L & TRES-L & TRES-S & GOV-S \\
\hline Access to funds & $\begin{array}{l}\text { Typically low, } \\
\text { since they } \\
\text { cannot generate } \\
\text { much revenue } \\
\text { locally. }\end{array}$ & $\begin{array}{c}\text { Scant funds } \\
\text { available for } \\
\text { operation and } \\
\text { maintenance of } \\
\text { the ICT } \\
\text { infrastructure. }\end{array}$ & $\begin{array}{l}\text { Better access } \\
\text { to funds; Can } \\
\text { invest in ICT } \\
\text { infrastructure. }\end{array}$ & $\begin{array}{l}\text { Have better } \\
\text { access to funds } \\
\text { when compared } \\
\text { to other groups. }\end{array}$ \\
\hline $\begin{array}{c}\text { Access to } \\
\text { infrastructure }\end{array}$ & $\begin{array}{l}\text { Only stand- } \\
\text { alone bill } \\
\text { generation; not } \\
\text { directly } \\
\text { connected to } \\
\text { the PICT } \\
\text { network. }\end{array}$ & $\begin{array}{c}\text { Poor } \\
\text { infrastructure }\end{array}$ & $\begin{array}{l}\text { Good access } \\
\text { to } \\
\text { infrastructure. }\end{array}$ & $\begin{array}{l}\text { Good access to } \\
\text { infrastructure. }\end{array}$ \\
\hline $\begin{array}{l}\text { Access to skilled } \\
\text { human resources }\end{array}$ & $\begin{array}{l}\text { Very few } \\
\text { competent } \\
\text { personnel. }\end{array}$ & $\begin{array}{l}\text { Very few } \\
\text { competent } \\
\text { personnel. }\end{array}$ & $\begin{array}{c}\text { Good access } \\
\text { to human } \\
\text { resources. }\end{array}$ & $\begin{array}{l}\text { Good access to } \\
\text { human } \\
\text { resources. }\end{array}$ \\
\hline ICT-readiness & Poor & Poor & Good & Good \\
\hline
\end{tabular}

Table 4. A summary of the status differences

Although the local groups raised their own revenue, they largely depended on grants from the state groups to fund public services. GOV-S groups controlled both planning as well as budgetary allocations. On average only about $6-10 \%$ of the total expenditure incurred 
annually in the state was spent on the local groups. The state groups clearly had greater access to funds compared to the local groups. As a TRES-L member put it:

The power given to us is very limited [...] as you can see for yourself we could do with improved working conditions [...] but my hands are tied [...] for sanctioning bigger amounts I have to pass it to my higher ups. GOV-S has to come into the picture. If there is an urgent need, I just cannot do anything about it.

While the state groups could access and disburse funds easily, there was a cap on the discretionary funds allocated to the local groups, a small figure that had not been revised for more than a decade. The state groups had better access to infrastructure. By infrastructure, we refer to the supporting facilities, which enable the effective use of the PICT system. Even at the time of our data collection, local groups were only given a stand-alone application which generated all the data. This data had to be delivered manually to the nearest TRES-L office, which in the majority of cases was accomplished using antiquated floppy diskettes, a practice that hadn't changed for over a decade. These arrangements were hardly ideal. As GOV-L members observed:

See, for any minor correction we have to send someone multiple times over. Sometimes if the problem cannot be solved at the TRES-L level there is no way we can resolve it sitting here. We have to make trips to $X X X X$, the administrative capital city of the state. We would not have this problem if we had networked computers at our office.

and

Many times when we send the data to the treasury (TRES-L), they say the floppies are not working. So we even end up spending our own money to buy floppies. 
These difficulties of the local groups were in stark contrast to the privileges enjoyed by the state-level groups. The offices of the GOV-S groups were located in the same large modern city where TRES-S's office was also located. Furthermore, given the better access to funds, they used more reliable data transfer technology such as a USB flash memory. The local groups were also particularly affected by the frequent and arbitrary transfer of knowledgeable employees. On many occasions TRES-L members, who had reasonable expertise in managing and operating the PICT system were transferred without warning to a completely different government body by the state groups. Coupled with inadequate training and capacity building programs, these arbitrary transfers ensured that the local groups were always short of skilled human resources. Although they were the operators of the PICT system at the local level, TRES-L groups received very little training on the system. The following quote from a state group bureaucrat exemplifies these problems:

Training is usually "on the job". There are no specific training programs for them. It is true that by the time they get to know the system, many of them (the TRES-L members) are transferred to other postings. But we are not a training agency, we have other priorities [...] there are other state and local agencies who are responsible.

An important fall-out of the differential access to resources was that the ICT-readiness of the local groups remained at a fairly basic level. By ICT-readiness, we refer to the ability and willingness of the state and local groups to use ICT. In particular, GOV-L members were unfamiliar with ICT and had serious difficulties in adapting to computerized systems. This had the unfortunate effect of further widening existing status gaps. The state groups now viewed themselves as expert users of the PICT system while expressing scorn at the perceived failings of the local groups and looking down upon them. In the words of a GOV-S member: 
We now upload all orders signalling release of funds online on our website, but still the GOV-L groups wait for the hard copy of the order to arrive to begin work! They believe the hard copy is more authentic.

Thus, the processes of release and utilization of funds was invariably delayed. While GOV-L members complained about the delays and the poor access to infrastructure, GOV-S members were quick to patronize, pointing to the lackadaisical attitude and poor ICT skills of GOV-L members.

\subsection{Institutional logics, Status differences and Continuity}

Informants at the state group level admitted they had felt threatened initially by the aspirations of the PICT project to devolve control and power to the local groups. They were worried about a potential upgrading of the local groups' statuses and a corresponding downgrading of their own status. They responded to this perception of threat by excessive bureaucratic posturing, which allowed them to control and dominate the local groups. As a GOV-S member boasted:

There are about Rs 8000 crores (about US\$135 million) worth of schemes and programs which can be handed over to the local governments. These schemes were earlier a part of the local governments. But now we have taken them back and will continue to take control of such schemes.

In other words, taking advantage of the logic of a centralized bureaucracy, the state groups adopted a high-handed approach and appropriated funds meant for programs at the local level. Thus, the state groups made sure that the PICT project did not pose them any problems. In fact, they supported the project in its current form because it allowed them to 
continue to dominate the local groups. By their bureaucratic posturing, they were able to maintain their high status vis-à-vis the local groups:

There is nothing really wrong with the project. We still retain control. We want the project to continue. (GOV-S member)

Indeed, the local groups felt that the PICT project has served as a tool of control for the state groups. The following two quotes from GOV-L members capture the frustration of the local groups:

We don't even have control over our own funds. The state groups now have complete authority. What we have planned in our budgets is never given to us! We acknowledge that it (PICT project) has good intentions, but it also gave the state groups the opportunity to exert greater control over us.

and

It is a vicious circle, they won't let go of their power and with whatever they give us we are expected to reach our targets. When we don't, they blame it on our incompetence. They (state groups) are afraid that one day we will become strong local governments and that they might end up losing power.

Thus, the state groups drew on the bureaucratic logic to go against the devolution goals of the PICT project. They retained control of funds, provided very little support to the local groups and ensured the maintenance of the status differences between the state and local groups. The actions of the state groups, however, have not gone unchallenged. Informants in the local groups explained that they had held 'public rallies' and 'protest marches' where they raised demands for equitable allocation of funds. Put differently, local groups have not remained mute spectators to the bureaucratic manoeuvres of the state groups. They have 
started to use democratic processes (e.g., filing cases in courts against state groups) to fight for equitable access to funds via the PICT project. They have also filed petitions with highranking government officials, demanding that the state groups be ordered to transfer greater control of the PICT project to the local groups. A GOV-L member explained:

The idea of decentralization and the promise of ICT are very powerful. The PICT project has given us the confidence to negotiate for a better status. Yes, at the moment it is a struggle, but I have no doubt that we will gain status and be able to have access to more funds. It is just a matter of time.

It was evident that the local groups were drawing on the decentralization and technocratic logics and negotiating for a better status. A strong belief in the virtues of these logics has led them to negotiate vociferously for their rights. Some local group informants also suggested that the implementation of the PICT project further reinforced and promoted the values of decentralization and technocracy.

Why do we continue to support the project? Because it gives us hope and optimism. It gives us a starting point to negotiate and aspire for better access to financial resources

In short, the local groups viewed the PICT project as a vehicle of decentralization and technocracy. They endorsed the project and were prepared to overlook its current weaknesses because it promised long-term improvements to their status. Despite the misalignment between institutional logics (e.g., between the bureaucratic logic and the decentralization logic) and the prevailing status-related tensions, the local groups focused on (as a GOV-L member put it) 'working with the project'. While fighting against its ongoing distortions and failings, they mobilized resources at the local level to ensure that in its existing form the 
project at least served their immediate objectives. For instance, some local officials enforced adhoc corrective procedures to curb malpractices. A GOV-L member illustrated:

The clerk from $X$ department is asking me to clear this bill for the purchase of a jeep costing Rs 21 lakhs (about US\$35,000) without formal procedures. But I have put systems in place to check such malpractices. Every clearance has to go through me, and I have instructed them (TRES-L) to not accept any withdrawal requests without my approval.

Thus, despite its underperformance the PICT project continued on account of (a) the support it received from the institutionally ratified decentralization and technocratic logics, (b) the support it received from the state groups, a support linked to the fact that they were able to use bureaucratic posturing and continue their domination of local groups and (c) the support it received from the local groups, who believed the project was helping them reduce extant status differences.

\section{The PICT project continuity model}

Drawing on our analysis above, we next build a PICT project continuity model, which depicts and explains the simultaneous influence of multiple institutional logics and status differences on continuity. The model is presented in Fig. 4 below. Despite the presence of the favourably oriented decentralization and technocratic logics, the project faced the full brunt of the bureaucratic posturing of the state groups resulting in underperformance on several fronts. We would therefore argue that a competing bureaucratic logic, which allows for serious bureaucratic posturing can contribute to a PICT project's poor performance (see Fig. 4). At the same time, the complementary logics of technocracy and decentralization fully supported the project's aspirations to use ICT, devolve power and ensure equity. Thus, we 
argue that by virtue of being key cognitive schemas in the institutional environment, complementary logics enable PICT project continuity (see Figure 4).

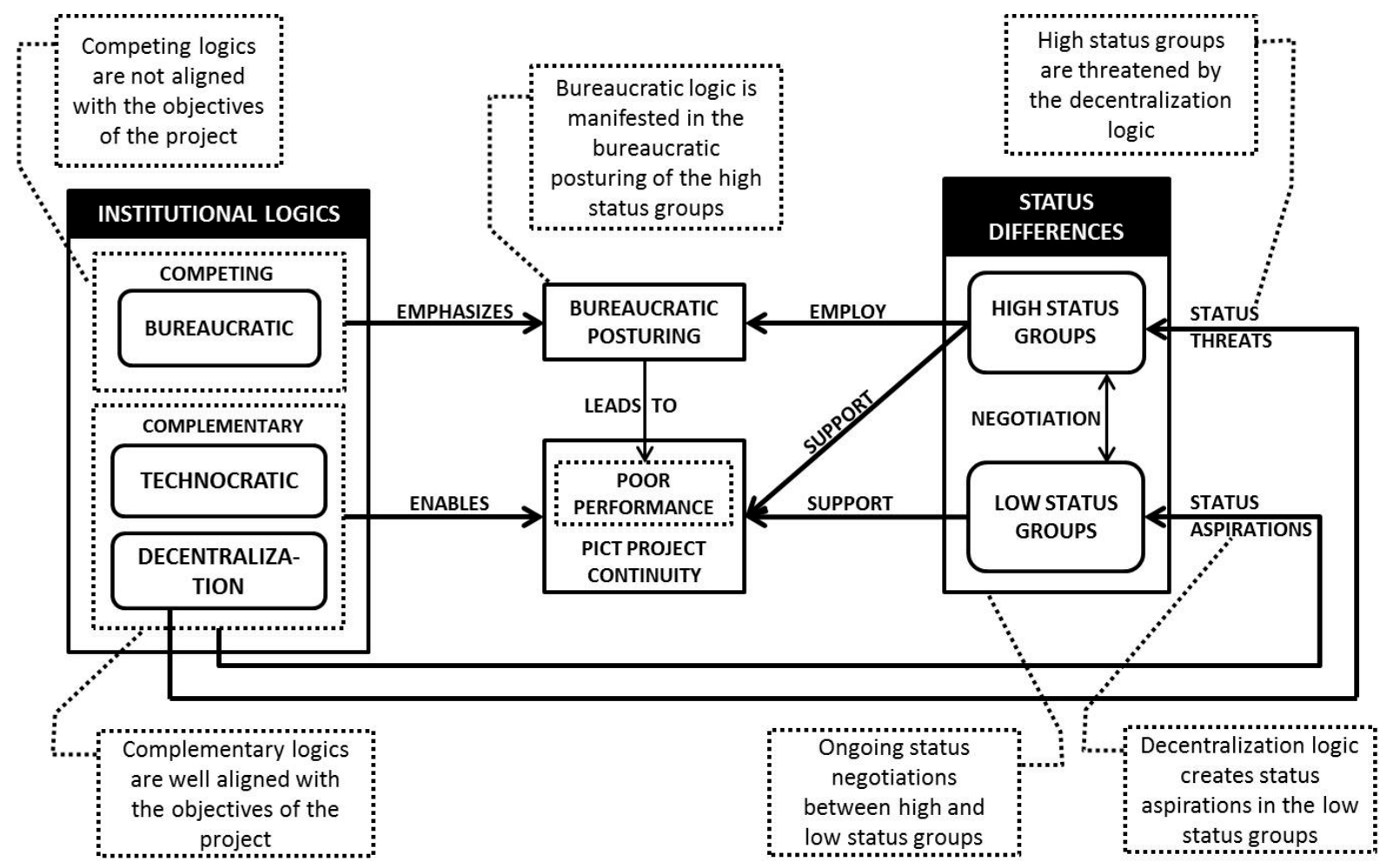

Figure 4. PICT project continuity model

There is another way to think about the underperformance of PICT projects. This explanation incorporates the role played by status differences. In our case, the state groups had a clear agenda. They wanted to maintain their high status for as long as possible. Their intention was threatened to the extent that the PICT project desired to decentralize control and power to the local groups. In response to such 'status threats' (see Figure 4) the state groups employed bureaucratic posturing (for e.g., they re-appropriated funds meant to be disbursed to the local groups). Thus, we may suggest that high status groups' bureaucratic posturing leads to the poor performance of PICT projects. However, as highlighted in our analyses and depicted in Figure 4, the same high status groups also support the continuity of the project because they are able to apply the bureaucratic logic and maintain status quo. Similarly the complementary logics can engender 'status aspirations' (see Figure 4) among 
the low status groups and lead them to support the continuation of the project. Drawing on the model above we propose that continuity can exist at two different levels: (1) the policy level and (2) the operational level.

\subsection{Policy-level continuity}

The decentralization and technocracy logics not only co-existed [see 36], but were also fully in sync with the objectives of the PICT project. In other words, these logics were strongly embedded in the institutional environment and supported the continuity of the project as a policy intervention, notwithstanding its underperformance. We may therefore refer to such a logics-driven continuity of the project as policy-level continuity. This suggests that as complementary logics gain a powerful foothold in the institutional landscape, they support and sustain PICT projects at a policy level. Our analysis also illustrates an important point about the framing of policy-level continuity. Despite its continuity as a policy intervention, the PICT project did not meet several of its objectives. The arguments about poor performance incorporate an inclusive view of continuity that also captures the perspective of the local groups. From the perspective of the state groups, however, the PICT project can be mostly viewed as a 'policy success'. By and large, they were able to establish control over what they viewed as 'adversarial' local groups. This shows how the framing of policy-level continuity in high status groups may openly contradict its framing in low status groups.

\subsection{Operational-level continuity}

At an everyday operational-level, both the state groups and the local groups worked with and supported the PICT project. The state groups drew on the bureaucratic logic and shaped the PICT project into a system that froze and maintained the existing status 
hierarchies ${ }^{2}$. Marti and Mair [29, p.101] argue that actors who are 'powerless, disenfranchised, and under-resourced...are also doing important institutional work'. This description fits the members of the local groups very well. They had a lower status and were disenfranchised and powerless to a large extent. However, they supported the project and facilitated its continuity at the operational level because they believed that the project could eventually lead to an upgrading of their status. The operational-level continuity of PICT projects in general can also be better understood by asking the question: Who actually has the authority to terminate PICT projects? Invariably, such decisions are taken at high-levels in the government, usually in line with political calculations and considerations. In our case, although the state groups and local groups were only two of the entities involved in such a decision making-process, all available evidence indicated that their support was crucial for the continuity of the project. In this Indian province, there were several instances of similar projects being terminated by the state, based on the negative feedback of the participating groups. However, in all the formal and informal feedback they have provided to high-ranking government officials in the finance department, the state and local groups involved in the PICT project have strongly supported the continuity of the project. This seems to reinforce the significant influence of status-related dynamics on the operational-level continuity of PICT projects.

\section{Theoretical contributions}

The literature suggests that the continuity of underperforming PICT projects could be underpinned by supportive institutional norms and beliefs [6, 34]. The notion of complementary logics introduced in this paper demonstrates the structure and process of such an institutional-level support. However, the 'underperformance' dimension of continuity

\footnotetext{
${ }^{2}$ We are grateful to Reviewer 2 for this insight.
} 
cannot be fully explained by elaborating the workings of complementary logics alone. The question is: how can projects continue underperforming despite the presence of supportive logics? In this paper, we have offered one possible answer. The institutional environment may also contain legitimate competing logics, which actors with vested interests employ frequently. Their self-serving actions could lead to an extended period of underperformance. Thus, from a broader perspective, unresolved tensions between complementary and competing logics may help explain the continued underperformance of PICT projects.

Theoretically, competing logics need not, of course always end in unfulfilled objectives. But what also need to be considered are the broader institutional contexts of countries like India, which are especially prone to what Khanna and Palepu [23] have termed institutional voids. While their discourse mainly relates to absent and ailing institutions in labour, capital and product markets, we would suggest that local government groups suffer most because of such voids. In other words, in countries like India, free-market institutions that can promote the cause of 'low status' local governments and lobby on their behalf are often missing. Thus, in our case, the application of the bureaucratic logic against the PICT project went on unabated with the state-level groups having to answer none of the tough questions that such a competing logic may have been otherwise subjected to (for e.g., through electronic media and public policy think tanks) in other contexts [34, 38, 39]. The presence of competing logics also draws attention to the role of human actors in the application of institutional logics [see 25, 44]. In institutional theory, logics are often viewed as socially shared cultural beliefs and assumptions, which inevitably guide action [27, 45]. Human actors are supposed to act strictly in accordance with the dominant logic in their institutional environment. The actions of the state groups, in our case, however, suggest that a more manipulative and calculating use of logics is also possible in an environment where multiple 
institutional logics prevail. Actors may deliberately employ a logic, which they are sure is in their self-interest (e.g., bureaucratic logic) and wilfully desist from invoking a logic, which might require them to give up some privileges (e.g., decentralization logic). Thus, while some processes of structuration [2, 13] were manifest in actors' (e.g. high status groups') reliance on institutional norms and practices, from a theoretical standpoint their actions also imply that human agency may reflexively take status hierarchies into account when deciding on which normative structure to apply in a given situation [see 53].

The complementary-competing logics highlighted in our study also throw light on the possible contradictions inherent in the implementation of a PICT project. Robey and Boudreau [37] argued that consequences of IT can be better explained by a logic of opposition (i.e. by examining forces both promoting change and impeding change). They suggest that IT implementations face opposing normative pressures. Our case empirically demonstrates the effects of such opposing institutional norms on the continuity of PICT projects. In any given institutional environment, complementary logics promote the changes a project is trying to bring about. However, the degree to which the project's goals are met may crucially depend on institutional forces, which defy the project. Put differently, the intensity and strength of competing logics - applied to pursue goals that openly contradict the changes desired by a project - can have a significant bearing on outcomes [12, 27]. Hence, we would argue that stronger the legitimacy enjoyed by competing logics, greater the likelihood of a project's continued poor performance.

Turning to the role of status differences in the continuity of underperforming PICT projects, our analysis illustrates how high status actors may offer their whole-hearted support to a project if they are able to shape and control its trajectory in ways that maintain current status hierarchies. While this insight is in line with earlier work [e.g., 1, 21, 22], our analysis also raises the possibility that low status groups too may support projects for long-periods of 
time when they frame it as a harbinger of positive change and as a symbol of hope for the future. They may recognize and come to accept that promised changes will be delivered in a laborious and long-drawn out process, even as they engage in everyday negotiations aimed at status upgrades.

In a recent paper, Karanasios and Allen [20] drew on activity theory to demonstrate how actors' incongruent and contested motivations underpin ICT interventions. They showed how implementation activities are made up of different entities with different motivations that act in concert to develop a project. Our study offers one useful way of theorizing such motivations. It suggests that motivations concerning 'status' and 'status differences' are crucial [see $21,35,53$ ] and may partly explain the continuity of poorly performing PICT projects. It shows how contrasting status-related motivations can drive different groups to support the operational continuity of the same project. As explained above, the prospect of maintaining current status differences could motivate one group to support a project, while the promise of reduced status differences could motivate a second group to support the same project. Thus, continued underperformance of a PICT project could be closely linked to a tense and contested ongoing process of status negotiation

Finally, it is important to recognize that continuity of a PICT project can itself have important impacts on institutional logics and status differences. As we highlighted in our analysis, continuity led to several organized attempts on the part of low status groups to negotiate for a better status. Such efforts suggest that continuity provide increased opportunity for status re-negotiations and can eventually help reduce status asymmetries. In this sense, statuses can be understood as negotiated, dynamic states that may alter over time $[35,52,55]$ because of the promise and potential of ICT. If, on the other hand, powerful competing logics develop alongside a PICT project, they might further exacerbate the existing status differences. On the whole, continuity could produce jolts in the system [see 17, 
45] and further strengthen or weaken particular institutional logics and status positions. Table

5 below presents a summary of our paper's main findings and contributions.

\begin{tabular}{|c|c|c|}
\hline $\begin{array}{l}\text { Prior literature } \\
\text { hints at the }\end{array}$ & $\begin{array}{l}\text { Key findings from the case } \\
\text { study }\end{array}$ & Theoretical contributions \\
\hline $\begin{array}{l}\text { Likely influence } \\
\text { of institutional- } \\
\text { level beliefs and } \\
\text { norms on how } \\
\text { PICT projects } \\
\text { unfold [6, 30, } \\
34 \text { ] }\end{array}$ & 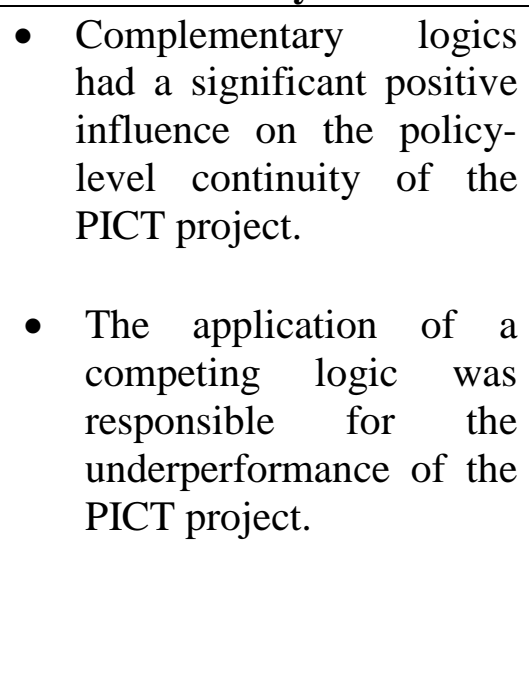 & $\begin{array}{l}\text { - PICT project continuity can be } \\
\text { conceptualized as a consequence of } \\
\text { the interplay of opposing institutional- } \\
\text { level forces. } \\
\text { - Human actors deliberately invoke } \\
\text { competing logics to protect their } \\
\text { interests and to retain greater control } \\
\text { over a project's future. } \\
\text { - Entities that call upon competing } \\
\text { logics are more likely to get away } \\
\text { with their actions in settings that } \\
\text { suffer from institutional voids. }\end{array}$ \\
\hline $\begin{array}{l}\text { Likely influence } \\
\text { of human } \\
\text { efforts to } \\
\text { maintain and } \\
\text { build status } \\
\text { asymmetries on } \\
\text { how PICT } \\
\text { projects unfold } \\
{[1,21,22] .}\end{array}$ & $\begin{array}{l}\text { - High status groups } \\
\text { supported the PICT } \\
\text { project's operational-level } \\
\text { continuity because they } \\
\text { were able to shape the } \\
\text { trajectory of the project to } \\
\text { their advantage. } \\
\text { - Low status groups } \\
\text { supported the PICT } \\
\text { project's operational-level } \\
\text { continuity because they } \\
\text { believed the project } \\
\text { would reduce extant } \\
\text { status differences. }\end{array}$ & $\begin{array}{l}\text { - Contrasting status-related motivations } \\
\text { drive different groups to support the } \\
\text { continuity of the same PICT project. } \\
\text { - Continued underperformance of a } \\
\text { project could be intimately connected } \\
\text { with on-going processes of status } \\
\text { negotiation. }\end{array}$ \\
\hline
\end{tabular}

Table 5. Summary of main findings and contributions

\section{Concluding Remarks}

In this paper, we have provided insights into the simultaneous influence of institutional logics and status asymmetries on PICT project continuity. We have also proposed a data-driven model that explains this process in-depth. The 'poor performance' 
dimension of continuity raises some troubling questions about the governance of PICT projects. The experience of our case suggests that the announcement and initiation of an ambitious project is often seen as an end in itself and equated with success. We would argue that it is equally, if not more, important for policy designers to show a commitment to setting up independent mechanisms of governance that oversee the implementation and orchestrate the intentions of PICT projects. In the absence of effective structures of governance, continuity can end up shielding many poorly functioning projects [34]. There may also be a tendency within governmental agencies to view a continuing PICT project as evidence that all stakeholders are well-served by it. We would argue that practitioners need to 'keep their ears to the ground' and interact frequently with low status groups in order to better manage the trajectory of PICT projects. Practitioners can over-estimate the power and reach of complementary logics to influence project outcomes and under-estimate the potency of competing logics to cause trouble. Our case suggests that in order to steer PICT projects towards reasonable outcomes it may be crucial for policy makers to be extremely sensitive to the dynamics of competing logics that can sabotage projects.

Notwithstanding its contributions, our paper has several limitations. Due to issues of access, we could not ascertain the views of the commercial vendors, who contributed to the implementation of the PICT project. They would have almost certainly given us more insights into the development process and the role played by state and local groups. Although none of our interviewees mentioned it as an issue, we acknowledge that in some contexts a PICT project may continue mainly because of the high switching costs involved in changing to a different ICT system. In other words, competing standards in software, hardware and telecommunications may act as a barrier for users to seamlessly move from one ICT system to another and may thus have a significant impact on continuity. We have not explored this dimension of continuity in any detail in our paper and would suggest that it is a worthwhile 
avenue for future research. Despite the negative portrayal of the bureaucratic logic in the empirical sections above, we acknowledge that some form of bureaucracy is actually a prerequisite for delivering public governance. It is only when the bureaucratic principles are applied in very rigid and dogmatic ways that PICT projects may hurtle towards poor performance. We have drawn on a single, intensive case of a PICT project in one Indian provincial state. While our findings may resonate with some countries with comparable administrative and governance systems, it clearly will not do so in all cases. Therefore, we would caution our readers before generalizing from this study to other contexts. We call for more empirical work to better understand the nature of PICT project continuity in other countries.

Although we have employed two interesting and important theoretical lenses, they are hardly exhaustive given the complexity and diversity of different implementation settings. Future work needs to explore in greater detail other possible influences on continuity such as the political embeddedness of projects and the role of private sector partners in delivering public services [6]. For instance, it would be interesting to see how continuity is affected when private sector vendors play a significant role in the operation and maintenance of a PICT project [see 34]. Structurally, there are a number of differences between emerging economies such as India and the more developed Western economies. But there are similarities too. Future empirical studies can extend our PICT project continuity model to the developed countries' context to compare and contrast the role of institutional logics and status hierarchies.

\section{References}

[1] D. Allen, Information systems as technological innovation, Information Technology \& People 13(3), 2000, pp.210-221. 
[2] J. Battilana, Agency and institutions: The enabling role of individuals' social position, Organization 13(5), 2006, pp.653-676.

[3] C. Bendersky, N.A. Hays, Status conflict in groups, Organization Science 23 (2), 2012, pp. 323-340.

[4] J. Berger, B.P. Cohen, M.J. Zelditch, Status Characteristics and Social Interaction, American Sociological Review 37(3), 1972, pp.241-255.

[5] J.S. Bunderson, R.E. Reagans, Power, status, and learning in organizations, Organization Science 22(5), 2011, pp.1182-1194.

[6] J. Bussell, E-governance and Corruption in the States: Can Technology Serve the Aam Aadmi?, Economic and Political Weekly 57(25), 2012, pp.77-85.

[7] Y. Chen, R.S. Peterson, D.J. Phillips, M.J. Podolny, C.L. Ridgeway, Introduction to the special issue: Bringing status to the Table-attaining, maintaining, and experiencing status in organizations and markets, Organization Science 23(2), 2012, pp.299-307.

[8] A. Choudhuri, ICT for Development: solutions seeking problems?, Journal of Information Technology 27(4), 2012, pp.326-338.

[9] W.L. Currie, M.W. Guah, Conflicting institutional logics: A national program for IT in the organizational field of healthcare, Journal of Information Technology 22, 2007, pp.235247.

[10] A. De Botton , Status Anxiety, Penguin, Canada, 2005.

[11] R. Delbridge, T. Edwards, Reflections on developments in institutional theory: Toward a relational approach, Scandinavian Journal of Management 23(2), 2007, pp.191-205.

[12] M.B. Dunn, C. Jones, Institutional Logics and Institutional Pluralism: The Contestation of Care and Science Logics in Medical Education, 1967-2005, Administrative Science Quarterly 55, 2010, pp.114-149.

[13] A. Giddens, Central problems in social theory: Action, structure and contradiction in social analysis, Macmillan, London, 1979.

[14] E. Goffman, Behavior in Public Places: Notes on the Social Organization of Gatherings, The Free Press, 1963.

[15] Government of India, Unique Identification Authority of India, http://uidai.gov.in/index.php/aadhaar.html, last accessed on April 2, 2012.

[16] R. Greenwood, C.R. Hinings, Radical organizational change, in: S. Clegg, C. Hardy, T. Lawrence and W. Nord (Eds.) The SAGE handbook of organization studies, Sage, London, 2006, pp. 814-842.

[17] R. Greenwood, R. Suddaby, C.R. Hinings, Theorizing change: The role of professional associations in the transformation of institutionalized fields, Academy of Management Journal 45(1), 2002, pp.58-80. 
[18] R. Heeks, Information Systems and Developing Countries: Failure, Success, and Local Improvisations, The Information Society 18, 2002, pp.101-112.

[19] R. Heeks, Implementing and Managing eGovernment - An international text, Sage, London, 2006.

[20] S. Karanasios, D. Allen, ICT for development in the context of the closure of the Chernobyl nuclear plant: an activity theory perspective, Information Systems Journal 23(4), 2013, pp. 287-306.

[21] M. Keil, Pulling the plug: software project management and the problem of project escalation, MIS Quarterly 19(4), 1995, pp. 421-447.

[22] K.C. Kellogg, Making the Cut: Using Status-Based Countertactics to Block Social Movement Implementation and Microinstitutional Change in Surgery, Organization Science 23(6), 2012, pp. 1546-1570.

[23] T. Khanna, K.G. Palepu, Winning in emerging markets: A roadmap for strategy and execution, Harvard Business Press, Boston, 2010.

[24] H.K. Klein, M.D. Myers, A Set of Principles for Conducting and Evaluating Interpretive Field Studies in Information Systems, MIS Quarterly Special Issue on Intensive Research 23(1), 1999, pp. 67-93.

[25] T.B. Lawrence, R. Suddaby, Institutions and institutional work, in: S. R. Clegg, C. Hardy, T. B. Lawrence, W. R. Nord (Eds.), The SAGE handbook of organization studies, Sage, London, 2006, pp. 215-254.

[26] N. Levina, E. Vaast, Innovating or doing as told? Status differences and overlapping boundaries in offshore collaboration, MIS Quarterly 32(2), 2008, pp.307-332.

[27] M. Lounsbury, A tale of two cities: Competing logics and practice variation in the professionalization of mutual funds, Academy of Management Journal 50(2), 2012, pp.289307.

[28] S. Madon, S. Sahay, J.Sahay, Implementing property tax reforms in Bangalore: an actornetwork perspective, Information and Organization 14(4), 2004, pp. 269-296.

[29] I. Marti, J. Mair, Bringing change into the lives of the poor: Entrepreneurship outside traditional boundaries, in: T. B. Lawrence, R. Suddaby, B. Leca (Eds.), Institutional work: Actors and agency in institutional studies of organizations, University of Cambridge Press, Cambridge, 2009, pp. 92-119.

[30] G. Miscione, Telemedicine in the Upper Amazon: Interplay with Local Health Care Practices MIS Quarterly 31(2), 2007, pp. 403-425

[31] A. Mukherjee, L. Nayar, Aadhar, A few basic issues, http://dataprivacylab.org/TIP/2011sept/India4.pdf , last accessed on Mar. 23rd 2013.

[32] S.L. Pan, B. Tan, Demystifying Case Research: A Structured-Pragmatic-Situational (SPS) Approach to Conducting Case Research, Information and Organization 21(3), 2011, pp.161-176. 
[33] S.K. Puri, S. Sahay, J. Lewis, Building participatory HIS networks: A case study from Kerala, India, Information and Organization 19(2), 2009, pp.63-83.

[34] M.N. Ravishankar, Public ICT Innovations: A Strategic Ambiguity Perspective, Journal of Information Technology 28(4), 2013, pp.316-332.

[35] M.N. Ravishankar, L. Cohen, A. El-Sawad, Examining resistance, accommodation and the pursuit of aspiration in the Indian IT-BPO space, Industrial Relations Journal 41(2), 2010, pp.154-167.

[36] T. Reay, C.R. Hinings, Managing the rivalry of competing institutional logics, Organization Studies 30(6), 2009, pp.629-652.

[37] D. Robey, M-C. Boudreau, Accounting for the contradictory organizational consequences of information technology: theoretical directions and methodological implications, Information Systems Research 10(2), 1999, pp. 167-185.

[38] S. Sahay, E. Monteiro, M. Aanestad, Toward a Political Perspective of Integration in Information Systems Research: The Case of Health Information Systems in India, Information Technology for Development 15 (2), 2009, pp. 83-94.

[39] S. Sahay, E. Monteiro, M. Aanestad, Configurable Politics and Asymmetric Integration: Health e-Infrastructures in India, Journal of the Association for Information Systems 10(5), 2009, pp.399-414.

[40] S. Sahay, J.I. Sæbø, S. Molla, A. Asalefew, Interplay of Institutional Logics and Implications for Deinstitutionalization: Case Study of HMIS Implementation in Tajikistan, Information Technologies and International Development 6(3), 2010, pp.19-32.

[41] C. Saunders, D. Robey, K.A. Vaverek, The Persistence of Status Differentials, in Computer Conferencing Human Communication Research 20(4), 1994, pp.443-472.

[42] H. Sminia, Institutional continuity and the Dutch construction industry fiddle. Organization Studies 32(11), 2011, pp.1559-1585.

[43] M.L. Smith, Limitations to Building Institutional Trustworthiness through EGovernment: A comparative study of two e-services in Chile, Journal of Information Technology 26(1), 2011, pp.78-93.

[44] P.H. Thornton, W. Ocasio, Institutional logics and the historical contingency of power in organizations: executive succession in the higher education publishing industry, 1958-1990, American Journal of Sociology 105(3), 1999, pp.801-843.

[45] N. Van Gestel, B. Hillebrand, Explaining stability and change: The rise and fall of logics in pluralistic fields, Organization Studies 32(2), 2011, pp.231-252.

[46] G. Walsham, Decentralization of IS in Developing Countries - Power to the People, Journal of Information Technology 8(2), 1993, pp.74-81.

[47] G. Walsham, Information systems strategy formation and implementation: The case of a central government agency, Accounting, Management and Information Technology 3(3), 1993, pp.191-209. 
[48] G. Walsham, Interpretive Case Studies in Is Research: Nature and Method, European Journal of Information Systems 4(2), 1995, pp.74-82.

[49] G. Walsham, S. Sahay GIS for district-level administration in India: Problems and opportunities, MIS Quarterly 23(1), 1999, pp.39-65.

[50] G. Walsham, D. Robey, S. Sahay, Foreword: Special Issue on Information Systems in Developing Countries, MIS Quarterly 31(2), 2007, pp.317-326.

[51] M. Weber, Economy and Society: An Outline of Interpretive Sociology, University of California Press, CA, 1978.

[52] S.P. Weisband, S.K. Schneider, T. Connolly, Computer-mediated communication and social information: Status salience and status differences, Academy of Management Journal 38(4), 1995, pp.1124-1151.

[53] A. Zimmermann, M.N. Ravishankar, Collaborative IT offshoring relationships and professional role identities: Reflections from a field study, Journal of Vocational Behaviour 78 (3), 2011, 351-360. 